\title{
Filistin ve Kudüs Meselesine Genel Bir Bakış (XIX. Yüzyılın Ortasından XX. Yüzyıl Ortalarına Kadar)
}

\author{
Hasan KARAKÖSE \\ Kırşehir Ahi Evran Üniversitesi, Fen Edebiyat Fakültesi Tarih Bölümü, Kırşehir \\ hkarakose@ahievran.edu.tr \\ ORCID ID: https://orcid.org/0000-0003-1853-8266
}

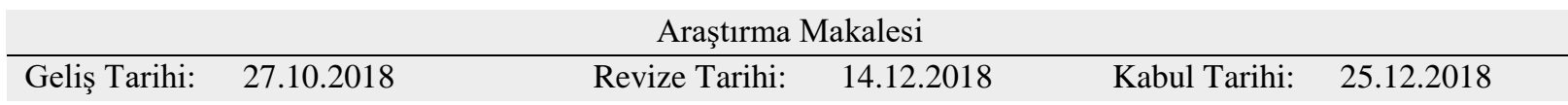

\section{Attf Bilgisi}

Karaköse, H. (2018). Filistin ve Kudüs meselesine genel bir bakış (XIX. yüzyılın ortasından XX. yüzyıl ortalarına kadar), Ahi Evran Üniversitesi Sosyal Bilimler Enstitüsü Dergisi, 4(2), 150-165.

ÖZ

\begin{abstract}
Makalenin konusu son iki asırda Filistin ve Kudüs'ün genel olarak sosyal ve siyâsî durumudur. Özellikle yirminci yüzyılda Orta Doğu'nun petrol ve Filistin olmak üzere iki önemli sanc1lı meselesi vardır.Son zamanlarda Kudüs Türkiye gündeminden hemen hemen hiç düşmemektedir. Bu bağlamda makalenin amacı Filistin ve Kudüs dosyasını bir daha hatırlatmaktır. İlk defa Filistin'de İbrahim Paşa zamanında katolik ve protestan misyoner okulların açılmasıyla Avrupa tarzı kültür hareketleri başgösterdi. Yahûdilerin Filistin için örgütlü olarak çalışmalarını 1861 tarihine kadar götürebiliriz. Bu tarihte İngiltere ve Fransa'da kurdukları cemiyetlerle, Yahûdîleri koruma ve Filistin'i Yahudi ülkesi yapabilme faaliyetlerine başlamışlar ve fikirde kalan bu hareketlerini 1882 tarihlerinden itibaren iki yolla eyleme dönüştürmüşlerdir. Birincisi Filistin'e göçler ve yerleşme çabalarıdır. İkinci sebep ise 1877-18778 Osmanlı Rus Savaş1 (93 Harbi)'ndan sonra, siyonistlerin Filistin'i yurt yapma düşüncesi ile uluslararası düzeyde girişimlerde bulunmalarıdır. Yahudilerin bu girişimlerine tepki olarak, Osmanlı devlet erkanı Filistin'e yapılacak Yahûdî göçünün var olan düzeni bozacağını düşünmüş ve Padişah İkinci Abdülhamid ve diğer devlet ricali Filistin topraklarında Yahûdî yerleşimine karşı engel olma siyasetini uygulamışlardır. Filistin meselesinde İttihad Terakkî Fırkası ilk zamanlar 1lımlı tavır sergilemiş fakat daha sonraları onlar da Sultan Abdülhamid'in Filistin siyasetini benimsemiş ve Yahûdî göçünü engellemeye çalışmışlardır. Birinci Dünya Savaşı ve İkinci Dünya Savaşı sonrası gelişen siyasi olaylar, Osmanlı hükümetlerinin haklılığını ortaya koymuştur. Günümüzde bölgede insanlık dramı yaşanmakta ve bunun tek sorumlusu büyük güçler ve İsrail'dir.
\end{abstract}

Anahtar Kelimeler: Filistin, kudüs, osmanlı devleti, sultan abdülhamid, israil

\section{An Overview Of The Palestinian Question}

\section{(From the Middle of the XIX. to the XX. Century)}

\begin{abstract}
The subject of the article is the social and political situation of Palestine and Jerusalem in the last two centuries. Especially in the twentieth century, the Middle East has two major painful issues, oil and Palestine. Lately, Jerusalem is almost never fall from the agenda of Turkey. In this context, the aim of the article is to remind the Palestinian and Jerusalem files. In Palestine, for the first time, during the time of Ibrahim Pasha, European-style cultural movements began with the opening of Catholic and Protestant missionary schools. We can take the work of the Jews for Palestine until 1861. On this date, with the societies they founded in England and France, they have started to protect the Jews and make Palestine a Jewish country, and From 1882 onwards, they transformed them into action in two ways. The first is migration to Palestine and settlement efforts. The second reason is that after the 1877-18778 Ottoman Russian War (93 War), with the idea of Zionists to make Palestine, they are undertaking international initiatives. In response to the Jews' attempts, The Ottoman government thought that the Jewish immigration to Palestine would disrupt the existing order and Sultan Abdulhamid II and other state officials implemented the policy of preventing the Jewish settlement in Palestine. İttihad Terakkî Party in the Palestinian issue had a moderate attitude but, later,
\end{abstract}


they adopted the policy of Palestine Sultan Abdulhamid and they attempted to hinder the Jewish immigration. First World War and political events after World War II, revealed the right of the Ottoman governments. Todays, the philistine is experiencing human tragedy and the only one responsible for it is the United States and Israel.

Keywords: palestine, jerusalem, ottoman empire, sultan abdulhamid 11, 1srael

\section{Giriş}

Adını M.Ö. XII. yüzyılda Avrupa'dan kavimler göçü sırasında deniz yolu ile buraya gelen Filistlerden alan Filistin, (Karaman, 1996) Arz-1 Kenan veya Arz-1 Mukaddes denilen yerin ismidir (Darkot, 1988). Coğrafi konum olarak Filistin, Akdeniz'in güney doğu ucunda Asya ile Afrika arasında köprü konumundaki yerdir. Esas itibariyle Filistin toprakları, Mısır, Akdeniz, Suriye, Şeria nehri arasında kalan topraklardır (Karaman, 1996).

Günümüz tarihçilerine göre M.Ö 5000'lerden sonra Arabistan dolaylarından bu topraklara ilk defa göç edip gelen ve Arapların atası kabul edilen Amalikalılardır. Daha sonraları Kenanlılar, Fenikeliler ve Ârâmîler gelip yerleşmişlerdir. Yine tarihçilerin çoğunluğuna göre Kudüs şehrini Kenanlıların bir kolu olan Yebûsîler kurmuşlardır (Karaman, 1996).

Hz. Musa'nın Mısır'dan çıkıp Yahûdilerle Sina Çölü'ne gelmesi yaklaşık olarak 1200'lerde Filistlerin buraya geldiği yıllara rastlamaktadır. Yahûdiler buradaki kavimlerle ve Filistlerle savaşmış, bölgenin büyük kısmını ele geçirmiş ve M.Ö. XI. yüzyılın sonlarında devletlerini kurmuşlardır. Daha sonra Kudüs'ü fetheden Davud, burasını kendisine başşehir yaparak bir de saray inşâ ettirmiştir. Davud zamanında İsrail Devleti'nin güçlenmesi ile bölgede yaşayan pek çok kavim hakimiyet altına alınmıştır. Davud'un ardından tahta çıkan Süleyman, Lübnan, Ürdün ve Suriye'nin bir kısmına sahip olmakla, devlet en parlak dönemini yaşamıştır. Süleyman Peygamber Kudüs'te kendi adı ile anılan bir mabed yaptırmıştır. Onun 932'de ölümünden sonra devlet ikiye parçalanmıştır. Bu parçalanmanın sonunda Yahûdiler bir daha kendilerini toparlama imkanına sahip olamamıştır (Karaman, 1996). Filistin toprakları M.Ö. 63 tarihinde Roma İmparatorluğu tarafından işgal edilmiştir. Bu işgale karşı Yahûdîler direnç gösterdilerse de fazla bir etkinlikleri olmamıştır. M.S.70 tarihinde Roma prensi Titus tarafından bu defa Kudüs tamamen yağmalanarak tahrip edilmiştir. Roma İmparatorluğu 395 tarihinde ikiye ayrılınca bölge Bizans'ın elinde kalmış ve Filistin topraklarında Hıristiyanlık hızla yayılmaya başlamıştır. Kudüs bir ara 611 tarihinde Sasanî istilasına uğrasa da 629 tarihinde İmparator Herakleios tarafından Kudüs ve bütün Filistin yeniden Bizans hakimiyetine alınmıştır (Karaman, 1996).

Hz. Ebu Bekir'in son zamanlarında Bizanslılarla yapılan Ecnâdeyn Savaşı (634) sonunda Filistin ve Suriye'nin kapıları Müslümanlara açılmıştır. Bundan sonra Müslümanların bölgede yapmış oldukları Yermuk Savaşı (636), Kudüs'ün fethi (637) ve Kaysariyye'nin fethi (640-641) ile bütün Filistin Müslümanların eline geçmiştir. Özellikle Emevilerden Abdülmelik ve oğlu Velid ile Abbasiler zamanında bölgeye ve özellikle Kudüs'e büyük önem verilmiştir. Ayrıca Abbasiler zamanında Suriye ve Filistin bir eyalet haline getirilmiştir. Abbasiler zamanında 1071 tarihinde Atsız Kudüs'ü fethederek Abbasi halifesi ve Alparslan adına hutbe okutmuştur. Melikşah'ın kardeşi Tutuş 1079'da Suriye-Filistin Selçuklu Devleti'ni kurmuştur (Karaman,1996).

1099 yılında Haçlıların eline geçen Filistin Bölgesi Müslümanların eline geçene kadar acı günler yaşadı. ve karışıklıklar hiç eksik olmadı. 1187'de Selahaddin-i Eyyûbî'nin Kudüs'ü alması ile Filistin yeniden İslâmî bir karaktere bürünmüş oldu. Daha sonra 1291'de Memlukler eline geçen Filistin, 1516 tarihinde Yavuz Sultan Selim'in Misır seferi sırasında Osmanlı hakimiyetine girdi ve 1917 Aralık ayına kadar Osmanlı idaresi altında kaldı (Karaman, 1996).

Osmanlılar zamanında Arz-1 Filistin denilen bölge idârî olarak Şam eyaletine bağlı Kudüs, Nabluz, Gazze ve Safed sancaklarına ayrılmıştır. Yavuz Sultan Selim'in Filistin'i almasından itibaren kesintisiz Osmanlı hanedânı tarafından idare edilen Filistin, 1832 yılında Mehmed Ali Paşa'nın oğlu İbrahim Paşa'nın eline geçmiş olmakla birlikte yeniden 1840 tarihinde Osmanlı ailesinin idaresine girmiştir (Karaman, 1996). İbrahim Paşa zamanında Avrupâî siyaset doğrultusunda Filistin'de Katolik ve protestan misyoner okulları açılmış ve milliyetçi düşünceler aşılanmaya çalışılmıştır. Amerika, İngiltere ve Fransa'nın desteğini alan bu okullar Osmanlı Devleti'nin yıkılmasında etkili olmuşlardır (Dursun,1995). 
Yahûdiler Filistin'de yurt kurma çalışmalarını, İngilizlerin desteği ile 1861 tarihinde başlatmışlardır. Sermaye ve Avrupa devletlerinin desteği Filistin topraklarına göç eden Yâhûdiler 1948 tarihinde Filistin'de İsrail Devleti'ni kurmuş fakat bu arada tüm Orta Doğu'nun dengesi ve huzuru bozulmuştur.

Makale araştırma ve incelemeye dayanmaktadır. Konu ile ilgili kaynak kitap ve makalelerden faydalanılmıştır.

\section{Ondokuzuncu Yüzyılın Ortalarından Yirminci Yüzyılın Ortalarına Kadar Filistin}

1856 tarihinde İstanbul hükümetinin çıkarmış olduğu "Tapu Kanunu” toprakların sahipleri adına tescil edileceği ve bu kayıtlara tapu senetleri çıkarılacağı esasını getirmiştir. Bunun üzerine toprak sahipleri, arazilerinin kayıtlarını kendi adlarına yazdırmışlardır. Filistinli çiftçiler ise arazi vergisinden kurtulmak için, topraklarını kaydettirmede hayalî isimler kullanmışlardır. Yapılan bu hata pek büyük karışıklıklara yol açmış ve mirasçılar arasında kuşaklar boyu devam eden anlaşmazlıklar yaşanmıştır. Bundan faydalanmak isteyen zengin kesimler,birkaç köyün arazisini üzerlerine kaydettirme firsatını yakalamışlardır. Ayrıca bu zenginlerin ellerindeki arazileri yüksek fiyatlarla Yahudilere satmaları sonucu, Filistin için tehlikeli geleceğin alt yapısı hazırlanmıştır (Çelik,1993).

Yahûdilerin Filistin için çalışmalarını 1861 tarihine kadar götürebiliriz. Bu tarihte Londra'da kurulan ve amacı Arâzî-i Mukaddese (Filistin)'yi vatanlaştırmak olan "Londra İbranî Kuruluşu" ile aynı sene içinde Fransa'da kurulan ve dünya Yahudileri ile Filistin Yahudilerini korumayı ve kalkındırmayı hedefleyen "International İsrail Taahhüd Cemiyeti", Filistin'i Yahudi ülkesi yapma çabası doğrultusunda hareket etmişlerdir. Bu cemiyet 1870 tarihinde Yahudileri tarım alanında eğitmek için Filistin'de bir "Tarım Okulu” açmıştır. İleride de göreceğimiz gibi, Yahûdîlerin Filistin'e yerleşebilmek için taktikleri Osmanlı yönetiminden tarım için arazi satın alma maskesini kullanmışlardır (Çelik,1993).

Yahûdîlerin XIX.yüzyılın ikinci yarısından itibaren Filistin'e ilgilerini iki şekilde görmekteyiz. Birincisi Filistin'e göçler ve yerleşme çabalarıdır. Her ne kadar Avrupa Yahudileri ve özellikle de Doğu Avrupa Yahudileri 1850'lerden itibaren Filistin'e sınırlı olarak göç, etmeye başlasalar da (Aaronsohn,2003) artarak devam eden Rusya ve Doğu Avrupa'dan Yahûdî göç hareketleri gruplar halinde 1882 tarihinden itibaren başlamıştır. Bu bakımdan siyonist tarihçiler 1882 tarihini önemli bir başlangıç olarak kabul ederler (İslam Konferansı Teşkilat1,1988). Bu sırada Filistin Osmanlı Devleti'nin bir eyaleti konumundaydı. Filistin'e göç eden Yahudilerin ve özellikle de Rusya'dan gelenlerin ilk yaptıkları icraatları tarım arazileri satın almak olmuştur (Çelik,1993). Burada şunu belirtelim, Rusya'da Yahûdî düşmanlığının patlak vermesi Rus Çarı II. Aleksander'in 13 Mart 1881 'de öldürülmesi ve suikasttan önce teröristin bombaları bir Yahudi kadının evinde sakladığının anlaşılmasıdır. Bunun üzerine Rus yönetimi pek çok Yahudi'yi tutuklatmış ve halkın tepkisi giderek artmıştır (Biren,1993, Türk, 2007). Rusya'da anti-semitizmin önü alınmaz bir biçimde artmasıyla Yahûdiler Filistin'e göç etmeye ve yerleşip tarım arazileri edinmeye başlamışlardır (Armaoğlu, Trsz, Türk, 2007).

Yine 1882 tarihinde Doğu Avrupa'dan kaçan üçbin kadar Yahudi Filistin'e gelerek "Rişon Lozyon"dedikleri (Araplar "İyon Gara" derler) yerleşim yerlerini kurmuşlardır. Yahûdilerin Filistin'de bağımsız bir devlet kurmak istediklerini anlayan Sultan İkinci Abdülhamid, 1888 tarihinde çıkarmış olduğu bir kanun ile buraya yerleşmelerini yasaklamış ve Filistin'e ziyaret için gelen Yahûdîlerin, kalış sürelerini üç ay ile sınırlamıştır. Bu fikri destekler mahiyette Waşington'daki Osmanlı sefiri Ali Faruk Bey'in Mabeyn Birinci Kâtibi Tahsin Bey'e gönderdiği 22 Nisan 1898 tarihli şifre önemlidir. Bu şifrede Amerika'da merkezi olan gizli bir Yahûdî cemiyetinin Filistin'de bağımsız bir devlet kurmaya yönelik faaliyetlerde bulunduğu belirtilmekteydi (Kürkçüoğlu,1982). Yahûdîlerin Sultan Abdülhamid'e karşı aşırı düşmanlıklarının temelini bu kanuna kadar getirmek mümkündür (Nedim,1995, Nedşe, 2014).

Sultan Abdülhamid'in yasaklamalarına rağmen daha sonraki yıllarda Yahudiler Filistin'den daha fazla toprak alabilmek için çeşitli girişimlerde bulunmaya devam etmişlerdir. Örneğin 1898 senesinde "Yahudi İstimlak Bölgeleri Bankası"nı ve aynı sene içinde "Filistin'i Vatanlaştırma Kurulu" nu, 1901 senesinde ise Milli Yahudî Bankası"nı kurmakla ekonomik gücü silah olarak kullanmayı da ihmal etmemişlerdir (Çelik,1993). 
Yahûdilerin ikinci göç hareketleri 1904 yılında başlayıp I. Dünya Savaşı'na kadar aralıklarla devam etmiştir. İkinci göç dalgasıyla birlikte 40 bin kişi Filistin'e gelmiş olmasına rağmen, çeşitli sebeplerden dolayı birçoğu geldikleri memleketlere dönmek zorunda kalmışlardır.1904 ve 1906 yılları arasında Filistin'e gelenler gerçek iş̧̧i olmaktan uzak idealist kişilerdir. Bunlar Rusya ve Polonya'nın orta sinıfına mensup olan ve Filistin'de sosyalist bir toplum düzeni kurma idealinde olanlardır. İkinci göç ile Filistin'e gelen Yahûdîler, siyonist işçi hareketinin çekirdeğini oluşturan, işçi partilerini ,İsrail Devleti'ni kuran ve yönetenlerdir (Türk, 2007).Bir takım zorluklara rağmen, Doğu Avrupa'dan Filistin'e gelen göçmen sayısı yılda 3-5 binden aşağı olmamıştır. Birinci Dünya Savaşı başlarında Osmanlı topraklarında yaklaşık 420 bin Yahudi vardı. Yahudiler genellikle büyük şehirleri tercih ederlerdi. Örneğin Filistin'deki 120 bin Yahudi’nin üçte ikisi Kudüs’te yaşamaktaydı (Türk, 2007).

Yahûdîlerin XIX. yüzyılın ikinci yarısından itibaren Filistin'e ilgilerinin ikinci şekline gelince, XIX. yüzyılın son çeyreğine gelinceye kadar hem Filistin içinde hem de Filistin dışında Yahudîler diğer azınlıklar gibi barış içinde yaşamışlardır (Buzpınar, 2011).

Fakat bu barış içindeki yaşama ortamı 1877-18778 Osmanlı Rus Savaşı (93 Harbi)'ndan sonra Filistin'e yerleşmek isteyen yabancı uyruklu Yahûdîlerin giderek artması ve taleplerinde 1srar etmeleri ile durum değişmeye başlamış ve göç meselesi siyasî karaktere dönüşmüştür. Osmanlı topraklarında bu durumun oluşmasında Avrupa'da Yahûdî karşıtlığının giderek yaygınlaşması, Rusya ve Romanya'da Yahûdilere yapılan haksızlıkların artması, Filistin ve Yahûdî meselesinin çıkmasında en önemli etkenlerdendir. 93 Harbi'nden sonra Müslüman muhacirlerin Edirne ve İstanbul'dan artarak gelmeye başladığı bir süreçte devlet Yahûdilere de yardım etmiş ve onları da ülke topraklarına kabul etmiştir. Böyle bir ortamda pek çok Yahûdî İstanbul'a gelip yerleşmiştir. Benzer Yahûdî göçleri yirminci yüzyılın başlarına kadar aralıklı olarak devam etmiş ve gelenler Kıbrıs, Edirne ve Mezopotamya gibi Filistin dışındaki yerlere iskan edilmişlerdir. 93 Harbi'nden sonra başlayan bu gelişmelerden, Osmanlı Devleti Yahûdilerin esas niyetlerinin Filistin'e yerleşmek olduğunu anlamıştır (Buzpinar, 2011).

Osmanlı Devleti'nin 93 Harbi'nden sonra yaşadığı siyasî ve ekonomik sıkıntıların artması üzerine Avrupalı zengin bir kısım Yahûdîler, Osmanlı'ya krediler sağlandığı takdirde, Filistin'den toprak alınabileceği üzerinde durmaya başlamışlardır. İngiliz iş adamlarından Edward Cazalet 1878 tarihinde yayınladığı "Şark Meselesi” isimli makalesinde, İngiltere'nin menfaatlerini de dikkate alarak ve İngiltere'nin kontrolü altında Filistin'de bir Yahûdî devleti kurulabileceği fikrini ortaya atmıştır. Buna benzer konu Macaristan parlamentosunda da gündeme gelmiş, Filistin'in Yahûdîlere açılması ve burada Osmanlı'ya bağlı bir vilâyet veya bağımsız bir Yahûdî devleti kurulması görüşülmüştür. Fakat bunlar fikir olmanın ötesinde eyleme dönüşmemiş ve Osmanlı Devleti nezdinde herhangi bir girişimde bulunmamışlardır (Buzpınar, 2011).

Konu ile ilgili Osmanlı Devleti nezdinde ilk girişim İngiliz asıllı Hıristiyan Laurance Oliphant tarafindan yapılmıştır. Oliphant bu meseleye uzun bir zaman ayırdı ve hayatı boyunca bu uğurda çalışmalarda bulunmuştur. Oliphant ilk defa 1878 tarihinde düşüncelerini Filistin'de bir Yahûdî devleti kurulması taraftarı Yahûdî asıllı olan İngiltere Başbakanı Disraeli (Türk, 2007) ve Dışişleri Bakanı Salisburiy’ye açmıştır. Ona göre Yahûdîler Filistin toprakları için kırkbin sterlin para toplamışlardır. Bu para Osmanlı'nın Asya topraklarının 1slahı için harcanmalı, buradan toprak satın alınmalı ve bu topraklara Yahûdîler yerleştirilmelidir. Oliphant düşüncelerini eyleme dönüştürmek için 1879 tarihinde Filistin'e yolculuğa çıkmış ve Şeria nehrinin doğu yakasında bulunan Belka topraklarında incelemelerde bulunduktan sonra, buraların Yahûdîler için son derece uygun olduğu kanaatine varmıştır. Oliphant'a göre bu topraklarda pirinç, muz, şeker, pamuk portakal, incir gibi birçok sebze ve meyve yetişebilir ve bu topraklar verimli olduğundan gelecek için çok şey vaad etmektedir (Buzpınar, 2011).

1879 tarihinde İstanbul'a dönen Oliphant Filistin'de edindiği intibalarını bir rapor halinde Sultan Abdülhamid'e sunmuştur.Ancak bu tarihlerde hükümetin Mısır, Girit ve Yunan meseleleri, Nizâmiye Mahkemeleri'nin bağımsızlı̆̆ı, Anadolu'nun 1slahı,emniyet teşkilatının yeniden yapılandırılması meseleleri olduğundan, Oliphant'in raporu yeteri kadar ilgi görmemiştir.Yaklaşık bir yıl sonra İngiltere'nin İstanbul büyükelçisi Layard'ın padişaha müracaat etmesi ve konunun olumlu veya olumsuz karara bağlanması talebi üzerine 1297/ 8 Mayıs 1880'de konu Meclis-i Vükelâ'ya 
gelmiştir. Oliphant'ın raporunda; Filistin'de Osmanlı toprakları içinde yaşayan Yahûdîler dışında, başka ülkelerden gelen Yahudîlerin yerleşmesi için toprak satın alınacak, Belka arazilerine Müslüman mültecilerin yanısıra Yahûdîler de yerleştirilebilecek, gelen Yâhûdîlerin katkıları ve destekleri ile burada modern ziraatçilik yapılacak, elde edilen gelir ile bölge sanayii canlandırılacak, dışarıdan gelecek mültecilerin yerleştirilmesi için İskân-1 Muhâcirîn-i Osmanî Şirketi isminde ve Osmanlı hükümetinin denetiminde bir şirket kurulacak, hükümet Belka sancağından, Salt sancağına (günümüzde salt Ürdün'ün bir şehridir) kadar olan 1 milyon akar (4.356.000 dönüm) araziyi kurulacak şirkete satacak, üç yıl içinde Hayfa'yı Lüt gölüne bağlayacak bir demiryolu inşaa edilecek, Osmanlı hükümeti başka topraklar da satmak isterse, kurulacak şirkete teklif edecektir (Buzpınar,2011).

Kısaca özetlenen bu raporu bir gün sonra (9 Mayıs 1880) Meclis-i Vükelâ karara bağlamış ve padişaha sunulan kararla kesin bir dille reddedilince (Buzpınar, 2011), almış olduğu cevap üzerine hayal kırıklığı içinde ülkesine dönmüştür.1882 tarihine kadar İngiltere'de kalan Oliphant daha sonra, Yahîdilerin Filistin'e yerleştirilmesi için ikinci olarak bir daha İstanbulâ gelmiş ve Amerika'nın İstanbul büyükelçisi Wallace'ye yazılı müracaatta bulunmuştur. Amerika'nın İstanbul büyükelçisi Wallace, hükümet nezdinde girişimlerde bulunacağına söz vermiş ve Sadrazam Said Paşa ile temasa geçmiştir. Said Paşa verdiği cevapta "Yahudilerin 200 veya 250'şer gruplar halinde Halep veya Mezopotamya'ya yerleşebileceklerini ve çıkan yeni kanunla bunun herhangi bir sakıncasının olmadığını belirtmiştir (Buzpınar, 2011).

Geçen bunca zaman içinde Oliphant önce İngiliz devletine hizmet maksadıyla, sonra da Avrupa'nın çeşitli ülkelerinde zor durumda kalan Yahûdîlere yardım için Filistin'e göçün önündesi engelleri kaldırmaya çalışmıştır. Fakat Osmanlı devlet erkanı, Yahûdî göçünün Filistin'de var olan düzeni ve dengeleri bozacağı sonucuna görüşündeydi. Ayrıca Padişah II. Abdülhamid genel olarak Osmanlı topraklarına Yahûdîlerin göç etmelerine karşı olmamakla birlikte Filistin topraklarına Yahûdîlerin yerleşmesine karşı kesin bir tavır almış ve bu düşüncesini İngiltere'nin İstanbul büyükelçisi Layard aracılığı ile huzuruna çağırdığg Oliphant'a kesin bir dille asla kabul edemeyeceğini bildirmiştir. Padişah Sultan Abdülhamid verdiği cevapta oldukça haklı idi. Çünkü XIX. yüzyılın başından beri bölgede artan misyonerlik faaliyetleri sonucu, İngiltere, Almanya, Fransa, Rusya ve İtalya'nın kiliseleri, dernekleri, okulları ve diğer misyonerlik çalışmaları gereğinden fazla artmış ve bölge istikrarı her an bozulabilir duruma gelmişti. Eğer yabancı ülkelerden gelen Yahudîlerin Osmanlı vatandaşlığı sağlanırsa, Rusya ve diğer Avrupa devletleri Yahûdileri bahane ederek Osmanlı Devleti'nin iç işlerine daha fazla karışma imkânı bulmalarının yolu açılmış olacaktır (Buzpınar, 2011).

Oliphat'ın 1878 tarihinde başlatmış olduğu Osmanlı nezdinde Yahûdiler için toprak edinme girişimi dışında Theodor Hrzl'in İstanbul'â ilk gelişi olan 1896 tarihine kadar ikinci bir girişim olmamıştır. Theodor'un Yahûdî meselesine ilgi duyması, Avrupa 'da XIX. yüzyılın sonlarına doğru oldukça fazla yaygınlaşan anti-semitizmin bir sonucuydu. Tüm Avrupa'da giderek yaygınlaşan antisemitizm 1880’lere doğru Yahûdilerden her kesimi derinden etkilemiştir (Buzpınar, 2011).

1881 tarihinde başlayan anti-semitizm hareketlere karş1 Yahûdîler birtakım etkinlikler düzenlemişlerdir. Bu bağlamda ilk Filistin Konferansı 6 Kasım 1884 yılında Polonya'nın Kattowitz şehrinde yapılmıştır. Bunu 1887 ve 1889 yıllarında düzenlenen konferanslar takip etmiştir. Hoveve Siyon'un (Siyon Aşıkları) organize ettiği bu konferanslarda birçok tartışmalardan sonra, Yahudi göçü için Filistin'den başka bir yerin kabul edilemez olduğu kararına varılmıştır. Polonya'da bu çalışmalar yapılırken Batı Avrupa'da da akademisyenler siyonizme yönelik milli cemiyetler kurulmuştur (Türk, 2007).

Yahûdî Teodor Herzl'in 1896'da yayınladığg Yahûdî Devleti isimli eseriyle, Yahûdîlerde bir vatana sahip olma bilincinin oluşmasında küçümsenemeyecek katkısı olmuştur. Teodor Herzl'in 1897'de Dünya Siyonist Teşkilatı'nı kurması, Amerika ve Avrupa'daki zengin Yahûdîlerin çeşitli ülkeler çapında girişimleri ile bu faaliyetler hız kazandı (Armaoğlu, Trsz:). Bundan sonra Siyonistler bütün dikkatlerini Osmanlı toprağı olan Filistin'e çevirmişlerdir. Dr. Herzl padişah Sultan İkinci Abdulhamid'e, ekonomik sıkıntı içinde bulunan devletin bütün borçlarını gidermeyi ve bunun için otuz milyon sterlin vermeyi vaad etmiştir (Öke, 1993). Para vaadinde bulınurken, çabalarının imparatorluğun refah ve selametine yönelik olduğunu, Avrupalı büyük güçler gibi ülkeyi sömürmek 
değil, imar etmek istediklerini, Osmanlı yönetimine sadık vatansever bir Yahudi cemaati oluşturmak ve İmparatorluğa faydalı olmayı düşündüklerini söylemişlerdir (Öke, 2006).

Sultan Abdülhamit tahta çıktığında devletin borçları ödenemiyecek kadar yekün oluşturuyordu. Bunun üzerine padişah, "Muharrem Kanunnamesi”ni çıkardı ve Avrupalı alacak sahiplerinin birer temsilcilerinin İstanbul'da bulunmasını kabul etti. Bu kararı ile padişah, Osmanlı maliyesinin milletlerarası bir komisyon tarafindan kontrolünü önlemiş oldu (Öke, 1993),

Sultan Abdülhamit Doğu Avrupa'dan gelen Yahudilerin Filistin'e yerleşmesine şiddetle karşıydı. Ona göre, Filistin'e yönelen Yahudi göçünün ileride devletin başına büyük gâileler açabileceği bilincindedir. Avrupalıların kovduğu kişileri kabul etme taraftarı olmayan Sultan Abdülhamid, gelen Yahûdîler "Amerika'ya gönderilmeli veya Filistin'in dışında istedikleri başka yerlere yerleşebilirler" düşüncesindedir. Abdülhamit'e göre, Avrupa'daki Yahudiler Doğu'da yaşayan ırkdaşlarından daha fazla ekonomik güce sahip olduklarından birçok Avrupa devleti Yahûdî irkından kurtulabilmek için Filistin'e göçlerini teşvik etmekteydi. Yine ona göre Osmanlı Devleti'nde yeteri kadar Yahudi nüfusu mevcut olduğundan, Filistin'de Arap nüfusun azınlığa düşmesi durumunda Yahudiler yerleştikleri yerlerde kısa zamanda bütün gücü ellerine geçireceklerdir (Öke, 2006; Türk, 2007).

Bu kadar kapsamlı bir düşünceye sahip olan Sultan Abdülhamid, Yahudî meselesinin başgösterdiği ilk yıllarda siyonizme karşı bir takım özel tedbirler aldı. Bu tedbirler çerçevesinde nezaretler (bakanlıklar) arası iş birliği öngörülüyordu. Ayrıca Hariciye Nezareti yurt dışında faaliyetlerde bulunarak Siyonizm'in diğer devletler tarafından benimsenmesine karşı birtakım tedbirler alınacak, Dahiliye Nezareti siyonistlerin Filistin'e girişine engel olacak, bunun için güvenlik güçleri ve valiler gerekli önlemleri artıracaklar, hükümet göçmenlerin Filistin'de arazi satın almalarını engelleyecektir (Öke, 1993; İslam Konferansı Teşkilatı,1988).

Osmanlı Devleti'nin büyük çaba göstermesine rağmen Yahudiler Filistin'e göç etmeyi ve yerleşmeyi başardılar. Sultan İkinci Abdülhamid'in tahta çıktığı 1876 tarihinden II. Meşrûtiyet'in ilanına kadar siyonistler üç misli artmış ve 80 bine ulaşmıştı. Siyonistler bu süre içinde 40 bin dönüm arazi satın almış ve 33 yerleşim yeri (koloni) kurmayı başarmışlardır. Bu gelişmede Avrupalı devletlerin Osmanlı Devleti'ne yaptıkları baskıların büyük etkisi olmuştu. Diğer bir ifade ile Yahûdî meselesi Avrupalı devletler tarafından benimsenmiştir. Ayrıca Yahudilerin Filistin'e göçlerini kolaylaştırıcı önlemler alarak, kendileri açısından önemli bir sosyal problemi çözeceklerine inanmaya başladılar. Bir diğer üzerinde durulması gereken husus ise İngiltere başta olmak üzere Avrupalı büyük güçler, Osmanlı'yı parçalamak için etnik grupları politik amaçlarına alet etmekte ve bunların Osmanlı topraklarında ayrılıkçı hareketlerde bulunmalarına zemin hazırlamakta idiler. Bu sebeplerden dolayı Avrupalılar Filistin'deki Yahudilere yardım etmekten çekinmemiştir (Öke,1993).Yahûdilerin Filistin'e göçlerinin ve yerleşmelerinin önemli sebeplerinden birisi de yerli halkın tutumudur. Osmanlı yönetiminin Filistin ve Kudüs'e gelen Yahûdîlere karşı uyguladığı yasaklar uygulanmamış ve yerli halk tarafindan suiistimaller yapılarak göz yumulmuştur. Onun için de Filistin'e ziyaret için gelenler buradan bir daha çıkmıyorlar veya çıkarılamıyordu. Yahûdilerin yerli insanlara rüşvet vermeleri adeta bir gelenek haline geldiğinden, hükümet memurlarının takibat yapmaları nerede ise imkânsız olmuştur (Biren,1993).

Rusya, Almanya ve Avusturya-Macaristan Yahûdîleri ülkelerinden Osmanlı topraklarına gönderdikten sonra sadece ülkelerinde kendileri için huzursuzluk kaynağı olan bu 1rktan kurtulmuyor, aynı zamanda Osmanlı Devleti'nde yürüttükleri siyasetlerini elde etmek için kullanıyorlardı. Özellikle Almanya, Yahûdî göçmenlere yardım etmekten kaçınmamış ve Siyonistlerin Mezopotamya'da veya Filistin'de koloniler kurmalarını desteklemiştir (Öke, 2006).

Birinci Dünya savaşı boyunca Filistin'e gelip yerleşen Siyonist Yahudiler ile İngilizler arasında gizli dayanışmalar aralıksız devam etmiş ve Yahûdîler Osmanlı Devleti ile ilgili ellerinde bulunan bilgileri İngilizlere servis etmişlerdir. Bu hizmetlerine karşıllk İngilizler tarafından Yahîdîlerin Filistin'e yerleşmelerine müsaade edileceği vaadleri yapılmıştır (Nedim, 1995).

Ayrıca Birinci Dünya Savaşı devam ederken, İngiltere, Fransa ve Rusya arasında yapılan gizli görüşmeler sonucunda Sykes-Picot Anlaşması yapılmıştır (16 Mayıs 1916). Üç devlet oluş̧urdukları Ortadoğu'nun taksimi haritasında "kahverengi bölge" diye adlandırdıkları Filistin topraklarını 
savaştan sonra Avrupa devletleri denetiminde özel bir uluslararası idareye kavuşturma kararı aldılar (Karal, 2011). Filistin'e böylesi bir statü düşünülmesinin sebebi, İtilaf Devletleri arasında çıkan bir takım anlaşmazlıktır. Fransa, Filistin'in Suriye'ye dâhil edilmesini ve kendi nüfuz sahasına bırakılmasını isterken, İngiltere buna karşı çıkmıştır. Rusya ise bölgede Ortodoksluk savunucusu olarak Filistin'den dişlanmak istememiştir. $\mathrm{Bu}$ sebeplerle çok ortaklı uluslararası bir rejim çerçevesinde anlaşmaya varılmıştır (Kasalak, 2016).

8/9 Aralık 1917 tarihinde Kudüs İngiliz ordularının eline geçmiştir. Arkasından sırasıyla Nablus, Hayfa, Akka ve 21 Şubat 1918'de Eriha'nın Osmanlı Devleti elinden çıkması ile Filistin topraklarının önemli kısımları kaybedilmiştir (Emir (Erkilet), 2002). Kudüs'ün işgalinden kısa zaman önce İngiliz Dışişleri Bakanı Arthur James Balfour 1917 Kasım'ında Filistin'de Yahudiler için bir yurt oluşturulmasını ve bunu İngiltere'nin destekleyeceğini açıklamıştır (Bayur,1991; Kılıç, 2017). Balfour Deklerasyonu ile uluslararası bir güç olan ve 1881'den beri Yahûdî faaliyetlerini destekleyen İngiltere, siyonist projeye siyasi destek vereceğini tüm dünyaya ilan etmiştir. Bu deklerasyona İngiltere'nin yanında İtilaf Devletlerinin tamamı destek vermekle ortak bir anlaşmaya varmıştır (Ediz, 2015). Balfour Deklerasyonu, Filistin'in geleceği açısından yepyeni, bir o kadar da acı bir dönemi ve tartışmayı beraberinde getirmiştir.1917 öncesinde Siyonizm, göç hareketleri ve bir takım siyasi girişimlerle kendine zemin bulmaya çalışırken, deklarasyonla birlikte siyonizm uluslararası gündeme taşınmıştır (Ediz, 2015).

Filistin'de geçmişten beri Müslüman Araplar, Hıristiyanlar ve Yahudiler olmak üzere üç dinden olan kesim veya 1rk en önemli unsur olarak yer almıştır. Bölgede oran olarak diğer kesimlere göre ezici üstünlüğü bulunan Arapların büyük çoğunluğu Müslüman, küçük bir kısmı ise Hıristiyan'dır. Bu iki grubun toplamı bölge nüfusunun yüzde 90'lık kısmını teşkil etmektedir. Yahudiler ise toplam nüfusun yüzde 10'undan daha az kesimini oluşturmaktadır. Nüfus oranlarına bakıldığında çoğunluğu, İngiltere'nin bölgedeki politikalarına karşı olan Müslüman Araplar oluşturuyordu. Böyle bir nüfus yapısında siyonizmin Filistin'de yerleşebilmesi için İngilizler fazla çaba harcamaya gerek görmeden, Arapları karşısına alarak siyonistler lehine uygulama kararı almışlardır (Ediz, 2015).

Balfour deklerasyonunun açıklanmasından sonra İngilizlerin Şerif Hüseyin ve oğullarına verdikleri sözlerden vazgeçmeleri, siyonist işgalcilerin de Filistin'e daha etkin nüfuz etmelerine imkan vermiş̦tir. Ayrıca savaş sonunda imzalanan Versailles Anlaşması Filistin'de İngiliz mandasını tanımış ve Filistin'de Yahudilerin yerleşmesi için büyük kolaylıklar sağlamıştır (İslam Konferansı Teşkilatı, 1988; Turan, 2003).

İngilizlerin Filistin meselesine önem vermelerinin birçok sebebi vardır: Birincisi, İttihat ve Terakki Partisi yönetimi, ekonomik sıkıntıları azaltmak amacıyla Yahudi bankerlerinden borç alarak Yahudi göçmenleri Filistin'e yerleştirmeyi düşünmüş fakat Arap milliyetçiliğini de körükleyip tırmandırmak taraftarı olmamıştır. Bu amaçla Müslümanlarla Musevileri uzlaştırma düşüncesi gündeme gelmiş ve Müslüman-Musevi ittifak1 uzun görüşmelerden sonra 1913'de Paris'te bir ön protokolle yürürlüğe girmiştir. Bu durum başta İngiltere olmak üzere batılı devletleri kendi çıarlarını zedeleyeceği düşüncesi ile rahatsız etmiştir. Özellikle İngilizler, bu ittifakı bozmayı ve Osmanlı muhalifi bir Arap-Yahudi ittifakına dönüşmesi siyasetini gündemde tutmaya çalışmışlardır. İkinci sebep İngiltere için Hindistan'a açılan kara ve deniz ulaşım yollarının güvenliğidir. Süveyş Kanalı'nın, Mısır'ın ve tüm Mezopotamya'nın İngilizler tarafından denetim altında tutulması gerekiyordu. Belirttiğimiz her iki durum İngiltere için tampon bölge olması açısından Filistin'in konumu önem arz etmektedir (Kasalak, 2012 ). Bunların dişında İngiltere'nin Almanya ve Avusturya'da etkin olan siyonistleri kendi tarafına çekme siyaseti ve varlıklı olan Yahûdîlerden faydalanma yoluna girmiştir (Karaköse, 2018). En önemlisi de İngiltere siyonizmin oluşturacağı istikrarsılılktan yararlanarak bölge üzerindeki kontrolünü daha da güçlendirmek istemiş ve bütün sömürgeci güçlerin yaptığ 1 gibi azınlık Yahûdîlerin destekçiliğine soyunmuştur. Böylece İngiltere çoğunluğu oluşturan Araplara karş1 Yahûdiler yanında yer almıştır. Bunlara ilâveten Amerikadaki Yahûdî lobilerinin bu ülkedeki siyasetçiler üzerinde oldukça fazla etkileri olmuştur. Amerikan Yahûdîlerinin siyasî ve ekonomik desteğini arkasına alarak başkan seçilen Woodrow Wilson seçimlerden sonra minnet borcunu ödemek için önemli kilit bakanlıklara Yahûdî asıllı bürokratları getirmiştir. Böylece Yahûdîler İngiltere ve diğer Avrupa ülkelerinin desteğine ilaveten Amerikan desteğini de almışlardır (Turan, 2003). 
1919 Haziran ayında imzalanan Milletler Cemiyeti Sözleşmesi'nin 22. maddesi kapsamında İngiliz mandası içinde Osmanlı Devleti'nin eski Arap vilayetlerine geçici bağımsızlık tanıması kabul edilmiştir. Akabinde 1920 Nisan ayında yapılan San Remo Konferansı'nda İngiltere Filistin'de manda yönetimini üstlenmiş ve sivil manda yönetiminin yüksek askeri komiseri görevine başlamıştır (Bayur, 1991; Armaoğlu, Trsz). Bu tarihten itibaren Filistin meselesi yeni bir döneme girmiş ve İngiliz manda yönetiminde Yahudiler önemli görevlere getirilmiştir. Ayrıca Yahudilerin örgütlenmelerine, toprak almalarına ve Filistin'e göç etmelerine destekler artırılmıştır. Bu destekler ile kısa sürede Siyonistler iktisadî, siyasî ve mali güce ulaşlardır (Dursun, 1995).Bu arada 1933 tarihinde Almanya'da Nazilerin iktidara gelmesi ile Filistin'e Yahudi göçü daha da hızlanmış veya hızlandırılmıştır (Çelik, 1993 ).

Filistin'de Yahûdî nüfusunun artması ve demografik yapının gün geçtikçe bozulması, hızlı bir şekilde yerleşmelerin çoğalması, Araplar ile Yahûdiler arasında büyük silahlı çatışmaları başlatmıştır. Bu silahlı çatışmaların en sert olanları 1921, 1929, 1933 ve özellikle 1937'de yaşanan çatışmalarıdır. 1937'de başlayan Müslüman Arap-Yahûdî çatışmaları 1939 Mayıs ayında ancak yatıştırılabilmiştir. Özellikle üç yıl devam eden son çarpışmaların gelişmesinde 1933-35 yı1ları arasında 134.540 Yahûdî’nin Filistin'e göç etmesinin önemli bir etkisi olmuştur (Armaoğlu, Trsz:)

Filistinli Araplar, Birinci Dünya Savaşı sonrasında Siyonist Yahûdîlere karşı mücadelede dört farklı siyasi fikir hareketine bölünmüşlerdir. Bunlardan birincisi, Filistin topraklarında "Birleşik Arap Devleti" kurmayı amaçlayan Arap milliyetçiliğidir. İkinci olarak İngiliz işgalinden sonra Filistin'de ve diğer İslam ülkelerinde siyonizm karşıtlı̆̆ 1 yoğun bir biçimde artmıştır. Bu durumda Arapların en büyük korkusu, savaş sonrası Yahudilerin kitleler halinde göçleri karşısında azınlığa düşmektir. Bu kesim Filistin'in tamamen Yahudileşmesinden endişe duymalarına rağmen örgütlü olmadıklarından herhangi bir hareket içinde bulunmamışlar ve korkuları içinde kaybolmuşlardır. Üçüncü olarak temeli İslamî düşünceye dayanan siyasi hareket ki Müslüman dünyasıyla entegre bir Filistin isteyen İslamcılardır. Bunlar siyonizme karşı İslam dünyasını harekete geçirmeye çalışmışlardır. İngilizleri rahatsız eden en etkili gurup İslamî temele dayanan bu kesim olmuştur. Çünkü geniş Müslüman sömürge ağına sahip İngiltere, içinde İslami propagandayı barındıran her türlü oluşumdan endişe etmekte, tepki göstermekte ve geniş bir propaganda ağı ile bunları etkisizleştirmeye çalışmışlardır. Filistin'de etkili dördüncü grup ise milliyetçi, 1lımlı mandacılardır. İngiliz mandasından yana olan bu kesim, Filistin'in kendisini idare edemeyeceğine inanmaktayd1. Onlara göre bölgenin zenginleşmesi ve kalkınması için İngilizlerin siyasî ve ekonomik destekleri şarttır (Ediz, 2015). Benzer çatışmalar İkinci Dünya Savaşı ve sonrasında Yahûdilerin şiddet kullanması ile artarak devam etmiştir. Filistin'de İngiliz manda idaresi 15 Mayıs 1948'de sona erecekti. Bunun üzerine Siyonistler 14-15 Mayıs gece yarısından önce Tel Aviv'de İsrail Devleti'nin kurulduğunu ilan ettiler. Amerika Birleşik Devletleri Başkanı Truman İsrail devletinin kuruluş ilanından tam on bir dakika sonra, Sovyetler Birliği de bir gün sonra kurulan devleti tanıdıklarını açıklayarak desteklediklerini ilan etmişlerdir (Karaman, 1996).

\section{Ondokuzuncu Yüzyılın Ortalarından Yirminci Yüzyılın Ortalarına Kadar Kudüs}

"Bereket, mübarek olan" anlamlarına gelen Kudüs kelimesi yerine Beytülmakdis, Beytülmukaddes) isimleri de kullanılır (Harman, 2002; Dolu, 2016). Tarihi Bronz çağının başlarına kadar uzanan Kudüs şehrinin, Kenânlılar tarafından inşa edildiği görüşü oldukça yaygın kabul görmekle birlikte (İslam Konferansı Teşkilatı, 1988), İslam tarihçileri şehrin ilk kurucuları hakkında iki görüş ileri sürmektedirler:

Birincisi; Kudüs şehri, Hz. İbrahim döneminde bugünkü Akabe Körfezi, Lut Gölü ve Filistin topraklarında devlet kuran Amalikalılar tarafından kurulmuştur. İkinci görüş ise şehrin kurucuları Kenanlılar olduğudur. Zira bölgede M.Ö.1200'lerden önce var olan medeniyete Kenan Medeniyeti/ Uygarlığı denir ve şehrin kurucuları da bunlardır. Hz. Davud (M.Ö.1007-968) ise bu şehri Yebûsilerin elinden alıp kendisine başşehir yapmış, bir saray inşâ ettirip, şehrin etrafını duvarla çevirmiş ve adına Davud'un şehri ismini vermiştir (Harman, 2002).

Hz. Davud'dan sonra oğlu Hz. Süleyman (968-930) devletin topraklarını Suriye ortalarına kadar genişletmenin yanında en önemli eserlerinden birisi bir mabed (Süleyman Mâbedi / Mescid-i Aksâ) yaptırmasıdır. Mâbedin yerinde Hz. Süleyman'dan önce ilk defa Hz. İbrahim tarafından mescid yapıldığı ve aslının mescid yeri olduğu rivayetleri de vardır (Harman, 2002). 
Hz. Süleyman'ın ölümünden sonra varlığını uzun süre devam ettiremeyen İsrail Devleti yıkılınca, Kudüs, Perslerin, Makedonyalı Büyük İskender'in, Mısırlıların, Selefkîlerin, Romalıların eline geçerek sürekli el değiştirmiş̧tir. Romalılar M.S. 70'de Yahudileri buradan tamamen sürmesi üzerine dünyanın çeşitli yerlerine dağılmışlardır. Roma İmparatorluğu'nun yıkılması ile burası Doğu Roma denilen Bizanslıların elinde kalmıştır (Harman, 2002).

Hıristiyanların elinde bulunan Kudüs'ü İslam orduları başkumandanı Ebü Ubeyde b. Cerrah kuşatınca, şehir halkı Müslümanların Suriye şehirleriyle yaptıkları anlaşmalara benzer bir anlaşmanın kendileriyle de yapılması teklifinde bulundular ve şehri bizzat halifeye teslim etmek istediklerini bildirdiler. Hz. Ömer. Ebü Ubeyde'nin daveti üzerine Kudüs'e gelerek şehri Patrik Sophronios'tan teslim almış ve bir anlaşma imzalamıştır (638). Kudüs halkıyla yapılan bu anlaşma, cizye ve haraç vermeleri karşılığında mal ve can güvenliği, din ve ibadet hürriyeti esasını öngörmekteydi (Avc1, 2002). Şehir, Hz. Ömer zamanında Müslümanların eline geçyikten sonra, Beytü’l Makdis, Beytü'l Mukaddes, Kuds'ü-Şerif, Medinetü'l-Mukaddes isimleri ile anılmıştır (İslam Konferansı Teşkilatı: 1988).

Müslümanlar tarafından fethedilen Kudüs yeni bir döneme girmiş ve bundan sonra manevî bir kutup ve ilim merkezi olmuştur.1099 tarihine kadar Müslümanların elinde bulunan şehir bu tarihte Hıristiyan Haçlıların kırk gün süren kuşatmalarından sonra, onların ellerine geçmiştir. Müslüman halk, Kubbetü's-Sahra ve Mescid-i Aksa'nın bulunduğu kutsal bölgeye sığınıp canını kurtarmaya çalışmış fakat Haçl1lar dünyada eşi görülmemiş bir vahşet örneği sergileyerek evlerde, camilerde ve yollarda bulunan masum insanların hepsini kadın, erkek, yaşlı, çocuk demeden öldürmüşler, Mescid-i Aksa'ya sığınmış olanları da kılıçtan geçirilmiştir (Demirkent, 2002).

Selahaddin Eyyûbî Mi'raç kandiline denk düşen 2 Ekim 1187 tarihi Cuma günü Kudüs'e girmiş ve şehri Haçlılardan geri almıştır. Haçlıların seksen sekiz yıl önce kana buladıkları şehirde taşkınlıklar yaşanmamış, Müslümanlar zafer sevincini olgunluk içinde, ağır başlılık ve vakarla kutlamışlardır. Haçlılar Kudüs'ü terk ederken, Müslümanlar dışında yerli halktan Hıristiyanların ve Musevilerin de şehre yerleşmesine izin verilmiş, Hıristiyanlara ait kutsal yerlerin idaresi Ortodoks kilisesine teslim edilmiştir. Bir süre Kudüs'te kalan Selahaddin-i Eyyûbi, Haçlılar tarafindan saray olarak kullanılan Mescid-i Aksa'yı camiye çevirmiş, şehir yönetiminde gerekli düzenlemeler yapmış ve hasar gören şehrin surlarını tamir ettirmiştir (Demirkent, 2002).

Yavuz Sultan Selim'in Mısır seferi sırasında Osmanlı yönetimine giren Kudüs'e en büyük hizmeti Kanunî Sultan Süleyman yapmıştır. Kanunî Sultan Süleyman (1520-1566) Kudüs'ün şehirleşmesine çok büyük katkıda bulunmuştur. Kânûnî, 1538'de şehrin etrafinı dört km. uzunluğunda kare biçiminde surlarla yeniden yaptırmış, kaleyi restore ettirmiş, Kubbetü's-Sahra'nın duvarları ve kapısını yeniden tamir ettirmiş ve ayrıca Hz. Davud türbesini de inşâ ettirmiştir. Kendisinden sonra gelen Osmanlı padişahları da aynı geleneği devam ettirerek şehre çok büyük önem vermiş ve hizmette bulunmuşlardır (Demirkent, 2002).

Mısır Valisi Mehmed Ali Paşa'nın döneminde (1831-1840) Avrupâî tarzda ve katı bir biçimde önemli değişiklikler yapılmıştır.1834-1838 yılları arasında Kudüs'te katı uygulamalar, vergilerin arttırılması ve mecburi askerlik kararlarının yapılması kararları, bir takım ayaklanmaya sebep olmuştur. Halkın desteği ile Aralık 1840'da Kudüs yeniden Osmanlı yönetimine girmiş ve şehrin eski düzeni sağlanmıştır (Aselî, 2002).

Mehmed Ali Paşa dönemini ve Tanzimat'ın ilanını fırsat bilen yabancı güçler bölgede yoğun bir faaliyete giriştiler. 1838 tarihinde, İngiltere Kudüs’te ilk defa konsolosluk açtır. Arkasından Fransa, Avusturya, Prusya ve Rusya konsolosluklarını açmışlardır. Diğer taraftan misyonerlik çalışmalarına h1z verilerek 1841'de İngiliz Alman Protestan piskoposlukları kurulmuştur.1845'de Grek Ortodoks patriği İstanbul'dan Kudüs'e taşınmış, ayrıca Latin patrikliği de 1847 'de faaliyetlerini artırarak, çalışmalarını daha da aktif hale getirmek istemiştir (Aselî, 2002).

Avrulalıların Kudüs'te başlatmış olduğu kültürel, dini ve siyasi faaliyetler XIX. yüzyılın ortalarından itibaren daha da artarak devam etmiştir. Avrupa devletleri bir taraftan azınlıklara desteklerini devam ettirirken, diğer yandan Kudüs'te ve bölgede kendi nüfuzlarını artırma mücadelesine girişmişlerdir. Başta İngiltere Yahudileri himaya siyasetini üstlenmiş, Kudüs ve 
çevresinde Protestan merkezli Hıristiyan nüfusu artırma siyasetine soyunmuştur. Fransızlar Katolik cemaatleri, Ruslar ise Ortodoks gruplar üzerinde etkilerini yoğunlaştırmıştır (Aselî, 2002).

Avrupalıların çeşitli metodlarla bölgede ve Kudüs'te başlatmış oldukları yoğun faaliyetlere karşı Osmanlı yönetimi şehirde imar çalışmalarını artırma ve yabancıların nüfuzlarını kısıtlama çalışmaları olmak üzere iki yönden etkili olmaya çalışmıştır. Sultan Abdülaziz ve Sultan Abdülhamid zamanında şehirde yapılan imar çalışmalarından bazıları şunlardır:1863'te belediye idaresi ve bir idare meclisi kurulmuş ve belediye, şehrin temizliği, kanalizasyon sistemi, şehrin aydınlatılması, sokakların tanzimi ve ağaçlandırılması gibi alanlarda hizmetler vermeye başlamıştır. 1865 'te Kudüs'e telgraf getirilmiş, 1868'de Kudüs-Yafa karayolu hizmete girmiştir.1886'da şehirde polis teşkilatı gçrev yapmaya başlamıştır. Yafa Kapısı'nda 1900'de bir saat kulesi inşa edilen şehirde,1891 'de Kudüs belediyesi bir hastahaneyi hizmete açmıştır. XIX.yüzyılın ikinci yarısında ulaşım sistemi eskiye gore daha da iyileştirilmiş ve 1892 tarihinde Kudüs-Yafa demiryolu hizmete girmiştir. Ulaşım ve haberleşmedeki bu gelişmeler Kudüs'ün diş dünya ile ilişkilerinin gelişmesine, ziyaretçilerin daha çok gelmesine ve ekonomik açıdan canlılık kazanmasına yolaçmıştır (Aselî, 2002).

Kudüs'e ticari ve ekonomik kaynaklar bakımından baktığımızda kendisine yeterli gelir kaynaklarına sahip olmadığı görülmektedir. Şehirdeki tarım arazileri yetersiz ve sanayi için gerekli ham madde kaynakları yoktur. Fakat şehri her yönü ile besleyen en önemli gelirler, farklı dini yapılardan kaynaklanan zengin yapının olmasıdır. Kutsal dinlere mensup hacıların ve turistlerin ziyaretleri hem el sanatiarına hem de ticarete bitmeyen bir canlılık kazandırmıştır (Aselî, 2002).

Osmanlılar öncesi ve Osmanlı yönetimi boyunca Kudüs'te İslam dünyasının farklı bölgelerinden gelen pek çok Müslüman ulemâ Kudüs'e yerleşmiş ve ilmi hayata canlılık getirmişlerdir. Vakıfların desteği ile şehirdeki ilmi ortam cazibe merkezi olmayı sürdürmüş, ayrıca tasavvufi hayat buraya canlılık kazandırmıştır. Mescid-i Aksa ve Şam Kapısı civarlarında Mevleviyye, Şazeliyye, Rifaiyye ve Ahmediyye gibi tarikatlar dini ve kültürel hayata ayrı bir zenginlik kazandırmıştır. Fakat şehrin bu ilmî ve manevî yapısı XVIII. yüzyıldan itibaren gerilerneye başlamıştır. Bunun başlıca sebebi medreseler ve kültürel müesseseleri canlı tutan vakıfların zayıflamaya yüz tutmasıdır. İlmî konumun XIX. yüzyılın ikinci yarısına kadar devam etmesi sonucunda tüm Osmanlı topraklarında olduğu gibi eğitimde yenilikler dönemi başlamış ve yeni eğitim müesseseleri açılmıştır. Bunlar olurken yabancı devletlerin kurdukları misyoner okullarının kemmiyet ve keyfiyetinde artışlar bariz biçimde kendini göstermiştir (Aselî, 2002).

1881 tarihinden itibaren Rusya'daki baskılardan kaçan Yahudilerin Filistin'e göç etmeleri Kudüs'te önemli değişikliklere sebep olmuştur. Ayrıca Avrupalı Yahudilerin 1880'lerden sonra başlattıkları siyasî ve dini gerekçelerle başlattıkları göç hareketi 1882 'de siyonist politik kimliğe bürünmüştür. Yahudi göç dalgasının başlaması üzerine Osmanlı hükümetinin politikası değişmiş ve bundan sonra Filistin'de Yahudi yerleşimine engel olma siyasetini başlatan Sultan İkinci Abdülhamid, Yahudi göçünü engellemek için yoğun çaba sarfetmiştir. Padişah, Avrupa'dan kaçan Yahudilere Filistin'de toprak satın almalarını yasaklamak, hac maksadıyla şehri ziyaret edeceklere sadece geçici izin vermek ve vize koymak gibi kısıtlamalar getirmiştir. Osmanlı idaresinin toprak satın almayı engelleme siyasetine rağmen, istenilen sonuç alınamamış ve 1917 tarihine gelindiğinde şehirdeki Arap ve Yahudi nüfus yapısında belirgin değişim kendini göstermiştir. Kudüs'e gelip yerleşen Yahudiler daha çok eski şehrin kuzeybatı ve kuzeydoğusunda, Araplar ise şehrin kuzey ve doğusuna doğru yerleşim yerleri oluşturunca, şehrin sur çevrelerinde taşmalar başlamış ve böylece Yeni Kudüs yapılaşması ortaya çıkmıştır (Köse, 2015).

Kudüs Osmanlı yönetimine girince idârî olarak Şam eyaletine bağlı bir sancak haline dönüştürülmüş (İslam Konferansı Teşkilatı, 1988), 1887 tarihinde ise merkeze bağl1, bağımsız bir mutasarrıflık olmuştur. Bir y1l sonra 1888 tarihinde Beyrut vilâyeti oluşturulunca Kuzey Filistin'deki Nablus ve Akka sancakları bu vilayete bağlanmıştır. Böylece Filistin'in kuzeyi Beyrut valiliğine bağlanmıi, geri kalan kısım Kudüs mutasarrıflığında kalmıştır (Öke, 1993; Karaman, 1996). Kudüs, yirminci yüzyılın başlarında yeniden bağımsız sancak yapılmak suretiyle Taberiye, Hayfa, Akka sancağın sınırları dışında kalmak şartıyla, Sina Yarımadası'nın tamamı el-Arîş'in doğusundan Akabe Körfezi'ne kadar uzanan bir had, doğuda ise Lut gölü ve Şeria nehri bu sancak bölgesi kapsamında kalmıştır (Darkot, 1988). 
Birinci Dünya Savaşı sırasında Mısır'ın alınması için İngilizlere karşı kanal harekâtları yapıldığ 1 sırada Kudüs üs olarak kullanılmış ve savaş boyunca askerî lojistik amaçlı kullanmak için Sina Çölü'ne kadar uzanan 200 km.lik demiryolu inşâ edilmiştir. 3 Şubat 1915 tarihinde 16.000 kişilik ordu ile Birinci Kanal harekâtı seferi yapılmış fakat daha önceden oldukça fazla mühimmat hazırlığı yapan İngilizler karşısında başarısız olunmuş ve 4 Şubat 1915'de Osmanlı ordusu el-Arîş ve Birüssebi taraflarına çekilmek durumunda kalmıştır. 27 Temmuz 1916 tarihinde İkinci Kanal harekâtını başlatan Osmanlı orduları yine başarı elde edememişlerdir. 1917'de ise durum değişmiş ve Gazze'ye kadar gelen İngilizler şiddetli bir Osmanlı ordusunun direnci ile karşılaşmışlardır. Yeni gelişen şartlar üzerine İngilizler, 1917 yaz ayları boyunca hazırlıklara giriştiler ve işgal ettikleri yerlerde 350.000 ordu ve 500 topla askeri güçlerini takviye ettiler.19 Eylül 1917'de İngiliz kuvvetlerinin başında bulunan Allenby, Filistin'i tamamen işgal ederek Suriye'ye doğru yöneldi. Kasım 1917 tarihinde Türklerin Lut Gölü ile Gazze arasındaki karargahlarının bulunduğu cepheye saldırılarını sürdürerek Gazze, Yafa, Birüssebi ve Kudüs'ü işgal etti ve 9 Aralık 1917'de şehri tamamen ele geçirdi.1918 senesi başlarından itibaren sürekli geri çekilmek durumunda kalan Osmanlı ordusu Nablus, Hayfa, Akka ve 21 Şubat 1918'de Eriha'yı kaybedince, Filistin toprakları Osmanlı'dan çıkmış oldu (Darkot,1988; Karaköse, 2018).

1916 tarihinde Fransa ve İngiltere Filistin, Şam, Lübnan ve Batı Şeria’yı içine alan toprak parçasını Sykes-Picot Andlaşması ile paylaşma planları çizmişlerdi (İslam Konferansı, 1988). 1917'de Kudüs dâhil Filistin'in tamamı Osmanlı'nın elinden çıkanca yerli nüfusun büyük çoğunluğunu oluşturan Müslüman ve Hıristiyan Arapların topraklarına Avrupa ve Rusya'dan gelen Yahudiler yerleştirilmiş (Aselî, 2002) ve bölge 1920'ye kadar İngiliz askeri yönetiminde kalmıştır (İslam Konferansı Teşkilatı, 1988).

İngiliz yönetimindeki Kudü'te, nüfus, ekonomi ve kültürel bakımdan pek çok değişiklikler yaşanmıştır. Her şeyden önce Yahudi nüfusu Arap nüfusunu geçmiş ve ekonomik olarak Araplar, Amerika ve Avrupa'dan destek alan Yahudilerle ancak kendi imkânlarıyla mücadele edebilşr duruma getirilmiştir. Böylece Araplar ile Yahudiler arasındaki dengeler değişmiş ve daha da kötüsü Araplar aleyhine bozulmuştur. Başgösteren problemlerin içinden çıkamayan İngiltere, 1947'de Birleşmiş Milletler'e Filistin'i payiaştırma planını sunmuş ve Kudüs'e milletlerarası bir statü verilmesi teklifinde bulunmuştur. Bir yıl sonra 1948 Arap-İ̀srail Savaşı'nda Kudüs'ün batısı İsrail tarafından işgal edilmiştir. Ürdün ise eski şehir olarak bilinen Doğu Kudüs'te hâkimiyetini devam ettirmiştir. Böylece Kudüs Batı ve Doğu olmak üzere ikiye bölünmüştür. İsrail Ocak 1950'de Birleşmiş Milletler kararlarını hiçe sayarak Batı Kudüs'ü başkent ilan ederek resmi kurumlarını ve hükümet binalarını Kudüs'e taşınmıştır.1967 Arap İsrail savaşı sırasında Kudüs'ün tamamını işgal eden İsrail, günümüze kadar her türlü aşırı güç kullanmaktan çekinmeyerek şehri Yahudileştirme çalışmalarına devam etmektedir. Birleşmiş Milletlerin pek çok uyarıları ve kınamalarını kulak ardı eden İsrail, Kudüs ve diğer Filistin topraklarında bu siyasetini sürdürmektedir (Aselî, 2002).

ABD Başkanı Donald Trump, 6 Aralık 2017 tarihinde yaptığı açıklamada Kudüs'ü İsrail'in başkenti olarak tanıma vakti gelmiştir. Büyükelçiliği Kudüs'e taşıma talimatı veriyorum", diyerek Kudüs'ün İsrail'in başkenti olduğunu ilan etmiştir (Hürriyet Gazetesi, 1917). Bu söylemini 14.05.2018 tarihinde yürürlüğe koyan Amerika, büyük elçiliğini kanlı bir şekilde Tel Aviv'den Kudüs'e nakletmiştir.Eli kanlı İsrail askerleri 59 Müslüman Filistinliyi şehid etmiş, iki binden fazlası da yaralanmıştır (Habertürk Gazetesi, 2018).

\section{Sonuç}

Ondokuzuncu yüzyılın ortalarına kadar Filistin ve diğer Osmanlı topraklarında Yahûdiler ve diğer azınlıkların devletle proplemleri yoktu. Ne yazık ki Avrupa devletlerinin Osmanlı Devlti’nin iç işlerine müdahelesi bu yüzyılın ortalarında başlamıştır. $\mathrm{Bu}$ müdahele girişimlerinden birisi de Yahûdîler için Filistin'i yurt yapma çalışmalarıdır.1861 tarihinde İngiltere'nin desteği ile faaliyete başlayan "Londra İbranî Kuruluşu" ve aynı sene içinde Fransa'da kurulan "International İsrail Taahhüd Cemiyeti” bu alandaki ilk derneklerdir. Özellikle İngiltere bu tarihten. İsrail Devleti’nin ilan edildiği 1948 tarihine kadar siyonizm davasının en büyük destekçisi olmuştur.

Türkiye'de, Filistin meselesi denince genellikle Teodor Herzl'in, Sultan Abdülhamid'ten "Filistin'den toprak talebi" akla gelmektedir. Aslında unuttuğumuz veya unutturulan bir gerçek vardır 
ki, İngiltere'nin XIX yüzyılın ortalarından itibaren Orta Doğu'da Osmanlı hâkimiyetinde bulunan toprakları elde edebilmek için başlatmış olduğu İngiliz siyastidir. Örneğin Yahûdîler için Filistin'i yurt edinme fikrini ilk ortaya atan İngiliz iş adamlarından Edward Cazalet ve İngiliz asıllı Hıristiyan Laurance Oliphant'dır.

Birinci Dünya Savaşı devam ederken, 16 Mayıs 1916 tarihinde İngiltere öncülüğünde, Fransa ve Rusya'nın da kabul ettiği Sykes-Picot Anlaşması yapıldı. Bu üç devlet oluşturdukları Orta Doğu'nun taksimi haritasında "kahverengi bölge" diye adlandırdıkları Filistin topraklarını, savaştan sonra Avrupa devletleri denetiminde özel uluslararası idareye kavuşturma kararı aldılar. Bu tarihten yaklaşık bir buçuk yıl sonra Kudüs, Aralık 1917'de İngilizler tarafından işgal edilmişitr. İşgalden kısa süre önce, İngiliz Dışişleri Bakanı Arthur James Balfour 1917 Kasım'ında, Filistin'de, Yahudiler için bir yurt oluşturulmasını ve bunu İngiltere'nin destekleyeceğini açıklamıştır. 1861'den beri Yahûdî faaliyetlerini destekleyen İngiltere, Balfour Deklerasyonu ile de siyonist projeye destek vereceğini belirtmiştir. Bu deklerasyona İngiltere'nin yanında İtilaf Devletleri'nin tamamı da destek vermişlerdir.

1919 Haziran ayında Milletler Cemiyeti Sözleşmesi'nin 22. maddesi ile Osmanlı Devleti’nin toprağı olan eski Arap vilâyetlerine, İngiliz mandası himayesinde bağımsızlık verilmiştir. İngiltere, 1920 Nisan ayında yapılan San Remo Konferansı'nda, Filistin'de manda yönetimini üstlenmiştir. Bu tarihten itibaren Filistin meselesi yeni bir döneme girmiş ve manda yönetiminde Yahudiler önemli görevlere getirilmişlerdir. Böylece, Yahudilerin örgütlenmelerine, toprak almalarına ve Filistin'e göç etmelerine destekler artırılmıştır. Siyonistler, bu destekler ile iktisadî, siyasî, mali güce ulaştılar ve İsrail Devleti'nin kurulması için gerekli alt yapıyı hazırladılar. Sonunda İsrail Devleti 1948 tarihinde ilan edildi. Burada gerçek olan şudur ki,1861'den 1948 tarihine kadar İngiltere, İsrail Devleti'nin kurulmasında çok önemli görevler üstlenmiştir. İsrail Devleti kurulduktan sonra da Birleşmiş Milletlerin kurulmasına ön ayak olan yine İngiltere olmuştur. İngiltere'nin öncülük ettiği ve üstlendiği Yahudilik ve siyonizm davasının himayesini ve öncülügünü daha sonra Amerika üstlenmiş ve hala bu devlet yürütmektedir. İslam dünyası bu gerçeği unutmamalıdır.

Belirtilen bu gerçeğin dışında, Birinci Dünya Savaşı sıralarında Basra, Irak’ın tamamı, Akabe, Kutsal topraklar, Filistin, Ürdün, Lübnan ve Suriye gibi geniş Orta Doğu topraklarının Türklerin elinden çıkmasının yegâne müsebbibi yine İngiltere ve İngiliz siyasetidir. Makalede bu gerçek vurgulanmak istenmiştir. 


\section{Kaynaklar}

Aaronsohn, A. (2003). Türk ordusuyla Filistin'de, Çev: Necmettin Alkan, İstanbul: Selis Kitaplar

Habertürk.com (2018, Mayıs 15) Amerikan elçiliğinin Telaviv'den Kudüs'e taşınması, Habertürk Gazetesi, 1.

Hürriyet.com. (2017, Aralık 06) Amerika'nın Kudüs'ü İsrail'in başkenti olarak tanıması, Hürriyet Gazetesi, 1.

Armaoğlu, F. (Trsz.). 20. yüzyıl siyasî tarihi, İstanbul: Alkım Yayınevi.

Aselî, K. C. (2002). Osmanlı dönemi ve sonrası Kudüs, İstanbul: Diyanet İslam Ansiklopedisi, (26)334, 336-337.

Avcı, C. (2002). Fethedilişinden haçlı istilasına kadar Kudüs, İstanbul: Diyanet İslam Ansiklopedisi, (26), 327.

Bayur, Y. H. (1991), Türk inkılabı tarihi, 3(IV), Ankara: Türk Tarih Kurumu Yayınları.

Biren, M. T. (1993). II. Abdülhamid, meşrûtiyet ve mütareke devri hatıraları, 1, İstanbul: Arma Yayınları.

Buzpınar, T. (2011). Filistin'e yahûdî göçü meselesi (1878-1908), Devr-i Hamid, Sultan İkinci Abdülhamid, 5, Kayseri: Erciyes Üniversitesi Yayınları.

Çelik, M. (1993). Filistin, doğuştan günümüze büyük İslam tarihi, İstanbul: Çağ Yayınları,

Darkot, B. (1988). Filistin, İslam ansiklopedisi, 4. İstanbul: Millî Eğitim Basımevi.

Demirkent, I. (2002). Haçlılar dönemi Kudüs, Diyanet İslam Ansiklopedisi, (26), 330-332, 334-335

Dolu, A. (2016). Osmanlı kroniklerinde Kudüs algısı, Pamukkale Üniversitesi Sosyal Bilimler Enstitüsü Dergisi, 25(1), 22.

Dursun D. (1995). Ortadoğu neresi?, İstanbul: İnsan Yayınları.

Ediz, İ. (2015). Birinci Dünya Savaşı sonrasında Filistin'de toplum ve siyaset (1919-1922), Türkiye Ortadoğu Çalışmaları Dergisi, 2(2), 144-145, 148,150-151.

Emir (Erkilet), H. H. (2002). Yıldırım, Ankara: Genel Kurmay Başkanlığı Yayınları.

Harman, Ö. F. (2002). Kudüs, İstanbul: Diyanet İslam Ansiklopedisi, (26), 324- 325.

İslam Konferansı Teşkilatı Kudüs Komitesi Kararları (1988), Cidde: İslam Konferansı Teşkilatı Yayın1.

Karal, E. Z. (2011). Osmanlı tarihi, 9, Ankara: Türk Tarih Kurumu Yayını.

Karaman, M. L. (1996), Filistin, Diyanet İslam Ansiklopedisi, (13), 89-91,103,137-138,140.

Karaköse, H. (2018). Orta doğuda Osmanlı İngiliz mücadelesi (1876-1918 yılları arası),

Ankara: Nobel Yayınları.

Kasalak ,K. (2016). İngilizlerin Filistin politikası ve Filistin mandası, Süleyman Demirel

Üniversitesi Sosyal Bilimler Enstitüsü Dergisi, 3(25), 66-67.

Kılıç, R. (2017). 19. yüzyılda Osmanlı idaresinde Kudüs mutasarrıflı̆̆ı, Erciyes, 471,7.

Köse, F. B. (2015), Osmanlı dönemi Kudüs’ünde idârî ve sosyal yapı, Belgü, 2015 (1), 181.

Kürkçüoğlu, Ö. (1982). Osmanlı devletine karşı Arap bağımsızlık hareketi (1908- 1918), Ankara:

AÜSB. Fakültesi Yayını. 
Nedim, Ş. M. (1995), Filistin savaşı (1914-1918), Çev. Abdullah Es, Ankara: Genelkurmay Başkanlığı Yayını.

Nedşe, R. Ş. (2014), Sultan ikinci Abdülhamid ve Filistin, Çev. Necmeddin Gevri, İstanbul: Eşik Yayınları

Öke, M. K. (1993), Son dönem Osmanlı imparatorluğu, Doğuştan Günümüze Büyük İslam Tarihi, 12, İstanbul: Çağ Yayınları

Öke, M. K. (2006), Osmanlı imparatorluğu, siyonizm ve Filistin sorunu (1880-1914), Marife, 6 (1), 263-264

Turan, Ö. (2003), Medeniyetlerin çatıştığı nokta orta doğu, İstanbul: Acar Matbaacılık

Türk, F. (2007), Yahûdî devletinin demografik temelleri, birinci dünya savaşına kadar Osmanlı Devleti’nin Filistin siyaseti, Trakya Üniversitesi Sosyal Bilimler Dergisi, 9(2), 71, 73,78-79, 81. 


\section{Extended Abstract}

Until the middle of the nineteenth century, the Ottoman Empire had no problems with the Jews and other minorities in Palestine. First time, the Jews began their work for Palestine in 1861 with the support of England, establishing the association in London "London Hebrew Foundation". On the same date (in 1861), the "International Israeli Commitment Society was established in France, which wanted to develop the Palestinian Jews. Both associations wanted to make Palestine their homeland. Especially from this date, England was the biggest supporter of the Zionism case until the establishment of Israel in 1948. In this case, we need to know the supporter states behind the establishment of the Israeli State as Turkish society.

Sultan Abdulhamid and Teodor Herzl, who came to mind in the Turkish society in the case of Palestine. Because Sultan Abdul Hamid did not give Jews land from Palestine and he claimed the Palestinian cause. But the idea of providing homeland to the Jews in Palestine has always been the British. This is the fact that we have actually forgotten. In fact, the Middle East and other Ottoman lands should be the first to come to mind the game of British and British politics. For example, Edward Cazalet, a British businessman who first proposed the idea of a Palestinian homeland for the Jews, was British Christian Laurance Oliphant.

If you also need to give another example, as the First World War continued, the Sykes-Picot Agreement was held on 16 May 1916, under the leadership of Great Britain as a result of the secret negotiations that were accepted by France and Russia. The three states agreed to establish a special international administration under the control of the European states after the war. After the First World War,these states wanted to give Palestinian lands to the international administration under the control of European states. On the other hand, shortly before Jerusalem's occupation in December 1917, British Foreign Minister Arthur James Balfour announced in November 1917 that the creation of a dormitory for Jews in Palestine would be supported by the UK. Britain, which is an international force with the Balfour Declaration and which supports the Jewish activities since 1881, has declared to the world that it will give political support to the Zionist project. Along with the UK, the Entente States supported this declaration and reached a common agreement.

In June 1919, within the scope of Article 22 of the League of Nations Convention, it was accepted that the Ottoman Empire granted temporary independence to the former Arab provinces as a British mandate. At the San Remo Conference held in April 1920, the United Kingdom took over the mandate in Palestine and the high military commissioner of the civilian manda administration took office. From this date on, the Palestinian issue has entered a new era and the Jews have been brought to important positions under the British mandate. Great support was given to the organization of the Jews, their acquisition of land and their migration to Palestine. With these supports, the Zionists reached economic, political and financial power in a short time. The British have always been the British, who formed the infrastructure for the establishment of the State of Israel before 1948, and the establishment of the United Nations after the establishment of the Israeli state. In aour age, the tasks of England in the Middle East are fulfilled by America.

A part of the society in Turkey accused the Palestinian people or because of some mistakes made in the past or they argued that "The Palestinian issue is the case of the Arabs, does not concern us much" But it can be the fault of every society. Such errors can happen in every society. It is not correct to blame the Palestinians with some mistakes made about one and a half centuries ago. In 1917, after the Palestinian rule of Ottoman rule, with the Jewish immigration to the region and the demographic structure began. To defend their rights, the Palestinians engaged in armed conflicts with Jews between 1921, 1929, 1933 and 1937-1939. However, the Palestinians had to lose their land because Europe and America gave all kinds of support to the Jews. On the other hand,The Palestinians were undecided about the ways in which they would struggle against this great danger and fell apart. Thus, the Palestinian people lost their power. The Palestinians and the Islamic world have not yet set a common policy for Israel. Since the Islamic world does not have a common policy for the Palestinian issue, the blood flow in the region will not end. During the First World War, the only reason for the loss of Basra, Iraq, Aqaba, Holy Land, Palestine, Jordan, Lebanon and Syria was British and British politics. 
Finally, I would like to point out. Finally, I would like to point out this important issue During the First World War, the only reason for the loss of Basra, Iraq, Aqaba, Holy Land, Palestine, Jordan, Lebanon and Syria was British and British politics. In this article, this fact was asked to highlight. Turks and Muslims will not forget this fact. 